\title{
小児の膝蓋骨脱臼に対する半腱様筋腱移行術（上崎法）の成績
}

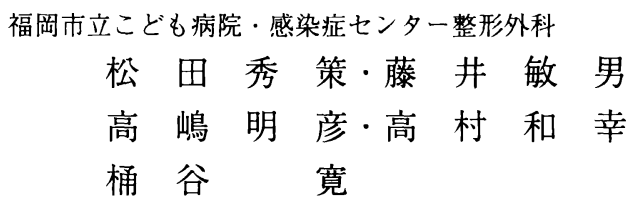

\section{Results of Semitendinosus Transfer (Uezaki's Procedure) for Dislocation of the Patella in Children}

by

Shusaku Matsuda, Toshio Fujii, Akihiko Takashima, Kazuyuki Takamura and Yutaka Oketani

Department of Orthopaedic Surgery, Fukuoka Chilrden's Hospital and Medical Center

We reviewed the results of 15 knees in 11 patients who underwent semitendinosus transfer (Uezaki's procedure) at Fukuoka Chilrden's Hospital and Medical Center from 1983 to 1996. Five patellae were permanent dislocations, 2 were recurrent and 8 were habitual. The mean age at the time of the operation was 8.1 years, and we examined the results after an average follow-up period of 5.3 years.

According to our own clinical evaluation methods, the results were satisfactory in 12 knees and unsatisfactory in 3 knees.

We examined the sulcus angle, tilting angle, congruence angle and the lateral shift ratio on X-rays. Most angles and ratios decreased except in the 3 unsatisfactory cases.

In the 4 unilateral cases, we found that the earlier surgical reduction was performed on the patella, the better the improvement in the shape of the sulcus of the patellar groove.

For the purpose of earlier diagnosis, we examined patello-femoral congruity on MRI scans of 1 case with nail-patella syndrome whose patella was not able to be viewed on X-rays.

We concluded early diagnosis and operative reduction was extremely important for the treatment of dislocation of the patella in children.

Key words : dislocation of the patella (膝蓋骨脱臼), semitendinosus transfer (半腱様筋腱 移行), sulcus angle, MRI scan

\section{はじめに}

小児の膝蓋骨脱臼は, 脱臼の有無やその病態を把握 することで適切な治療法が導かれるようだ。上崎 ${ }^{13-15)}$ の考案した半腱様筋腱移行術は, 膝屈筋力を能動的に 利用し，膝蓋骨を整復位に保つという特徵があり，骨 端線閉鎖前の症例に良い適応がある。
我々は，小児の膝蓋骨脱臼に本法を応用したので報 告する。

\section{調 査 対 象}

1983 年より 1996 年まで当院にて上崎法を施行した 11 例 15 膝（男 5 膝，女 10 膝）を調查対象とした。 手術時年令は 4.9-14.7 歳 (平均 8.1歳), 経過観察期 
間は 0.5-11.5 年 (平均 5.3 年) であった。

脱臼形式は permanent（常に脱臼状態にあるもの） 5 膝, recurrent（通常適合状態にあるが時々脱臼す るもの) 2 膝, habitual（膝関節がある屈曲角度にな ると常に脱臼するもの）8膝であった，原疾患の内訳 は permanent の中に先天性膝関節脱臼後 1 膝, nail patella 症候群 3 膝, 脚延長後 1 膝, recurrent の中 にEllis-van Creveld 症候群 2 膝, habitual の中に Down 症候群 2 膝であった。

\section{手術方 法}

手術方法は, 1975 年上崎が考案, 発表した原法に 準じて施行している（図 1). まず半腱様筋腱を黛足 部にて切離し, 近位まで充分引き出す.ついでlateral releaseを広汎に施行して膝蓋骨を整復位に保ち, 内 側を縫縮する. 更に整復を保持するため, 膝蓋骨内上 方より外下方に骨孔を作製し, 膝関節 $30^{\circ}$ 屈曲位に て, 半腱様筋腱を充分緊張した状態で移行し膝蓋骨前 面に縫着する．当院では近年, Goretex sheetを用 いて外側欠損部を覆い, 術後の癒着を防いでいる.

後療法は術後 3 週間ギプスシーネ固定し, その後自 動 ROM 訓練を施行しており, 通常他動訓練は施行 していない.

\section{調 査 方 法}

臨床症状は独自の評価判定法を用いた（表 1 ）。自 覚的所見として, 疼痛と giving way, 他覚的所見と して, ROM 制限, 再脱臼, 覀脱臼の有無について評 価し，全て陽性所見なしを satisfactory，1 項目でも 所見あれば unsatisfactory と評価した。

$\mathrm{X}$ 線学的計測は, sulcus angle, tilting angle, congruence angle, lateral shift ratio 4 項目 を調べた。また今回，顆間窩の骨性成長に着目し， sulcus angle と年齢との相関を検討した.

$$
\text { 結果 }
$$

臨床症状は satisfactory 12 膝, unsatisfactory 3 膝であった. unsatisfactory 症例は, 12 歳, 13 歳 といずれも高年齢手術症例であり，うち 2 膝は習慣性 で再脱臼を来し giving wayがあり，1膝は nailpatella 症候群で亜脱臼を呈するが giving wayがな かった。また全症例とも疼痛, ROM 制限は認めなかっ た.

sulcus angleは, 術前平均 $164.3^{\circ}$ が調査時平均 $155.5^{\circ}$ に改善し, 全症例とも不変または改善傾向を 示した.

tilting angleは, 術前平均 $53.5^{\circ}$ が調査時平均 $13.1^{\circ}$ に改善し, unsatisfactory の症例を除き，ほ ほ正常域だった。

congruence angleは, 術前平均 $82.1^{\circ}$ が調査時 平均 $15.9^{\circ}$ になったが, いわゆる正常域に達したも のは少なかった。これは膝蓋骨の形態が正常でないも のが多く，結果が一定しなかったためと思われた.

lateral shift ratio は, 術前平均 $81.2 \%$ が調查時 平均 $16.2 \%$ に改善し, 全例正常域に近い值を示した

表 1 評価法

\begin{tabular}{ll}
\hline \hline 1. 自覚的所見 : & $\begin{array}{l}\text { 疼痛 } \\
\text { giving way }\end{array}$ \\
2. 他覚的所見 : & $\begin{array}{l}\text { ROM 制限 } \\
\text { 再脱曰⿴, 亜脱曰 }\end{array}$ \\
\hline satisfactory : 全て $(-)$ \\
Unsatisfactory : 1 項目以上 $(+)$
\end{tabular}


(図 2).

sulcus angle と年跲との相関について，対象は健 常側と比較するため片側例 4 症例とした，全症例，脱 臼整復とともに sulcus angle が健常側值に近付き，

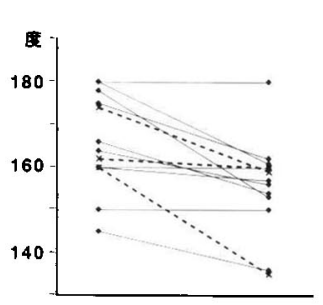

sulcus angle

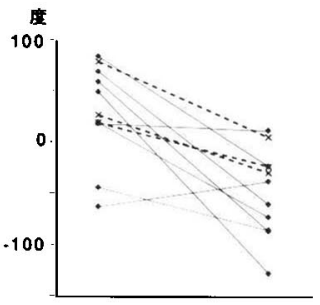

congruence angle

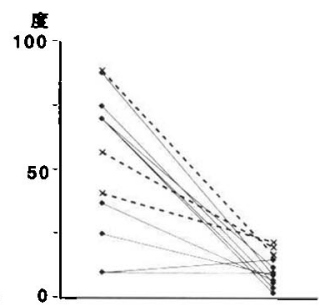

tilting angle

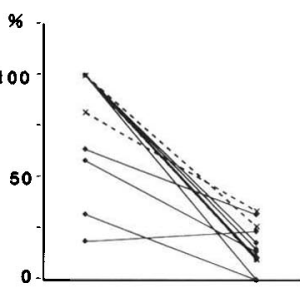

lateral shift ratio
図 2 術前, 調査時の X 線学的計測

実線は satisfactory 症例，点線は unsatisfactory 症例を示す.

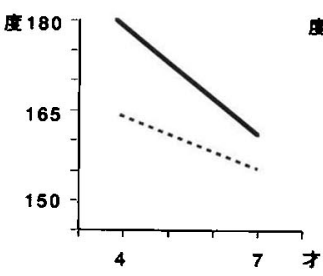

右先天性滕简節脱日後

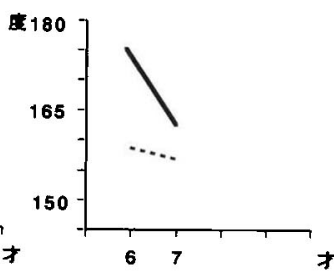

Down症侯群

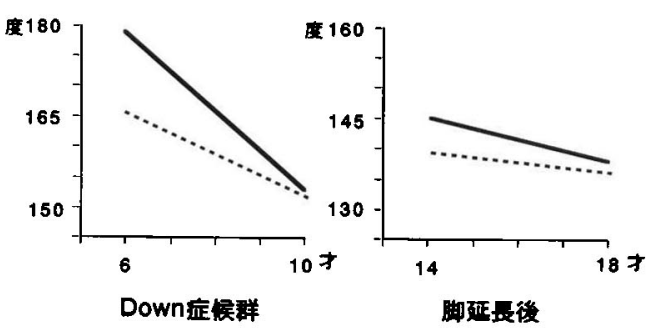

图 3 sulcus angle と年齢との推移

実線は患側，点線は健側を示す，若年例はどよ り早期に健常側値に近付いた。
若年例ほどより早期に健常側値に近付いた（図 3）。

症例 $1: 4$ 歳女性, 右先天性膝関節脱臼後の恒久性 膝蓋骨脱臼で，結果は satisfactoryである，術後 3 年でsulcus angle $180^{\circ}$ から $161^{\circ}$ と改善を認めた (困 4).

症例 $2: 12$ 歳男性, nail-patella 症候群の恒久性 膝蓋骨脱臼である，手術にて外側支帯の緊張が非常に 強く, patella tendon 外側にも解離を加えた。術後 5 年で顆間䆚の形成はみられるが, patella が外側に 偏位しており，严脱臼を呈したため，結果は unsatisfactoryであるが, 調査時, 疼痛, giving wayはな かった，前の症例と比較し 12 歳と高年齢で手術施行 しているため正常な膝蓋大腿関節の整合性が得られな かったと思われた（図 5).

症例 3:12 藏女性, 習慣性膝蓋骨脱臼で結果は satisfactoryである。術後 2 年で顆間窝はやや浅いが経

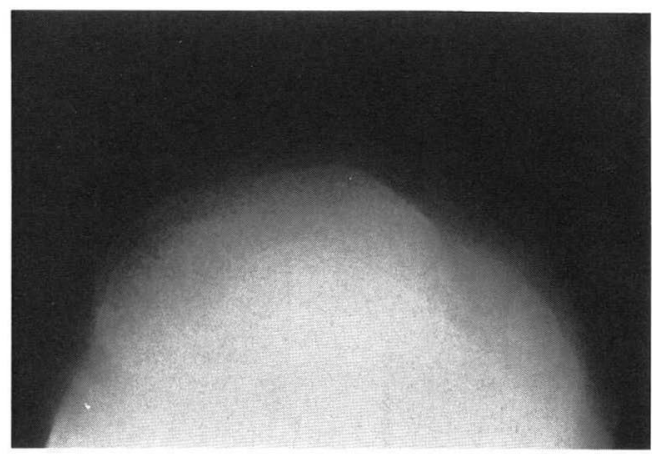

術 前

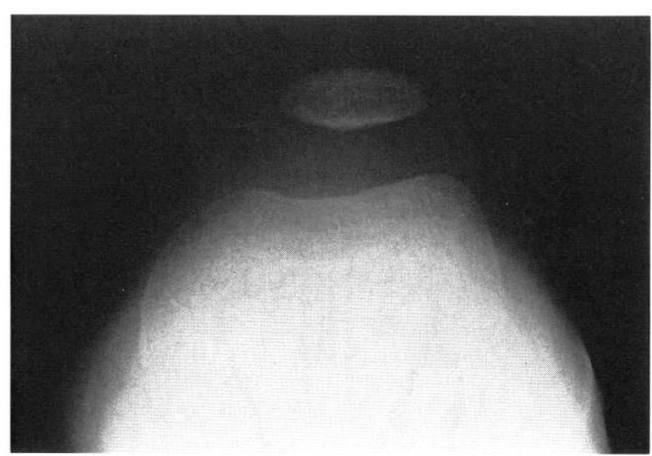

術後 3 年

図 4 症例 14 歳女性 先天性膝関節脱臼後の恒久性㮏蓋骨脱臼 (satisfactory). 術後 3 年で sulcus angle $180^{\circ}$ か ら $161^{\circ}$ と改善を認めた。 


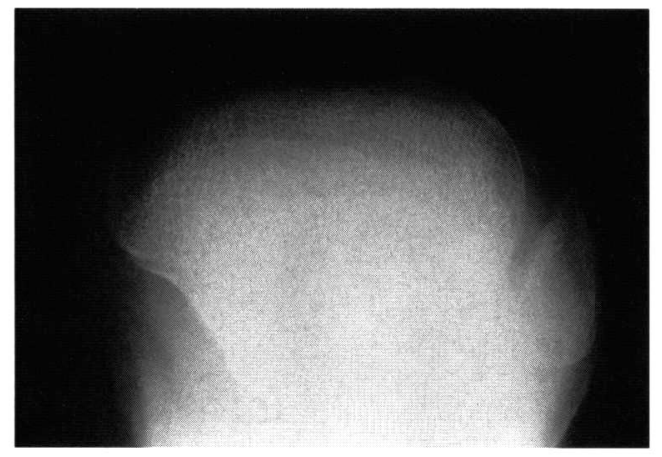

術 前

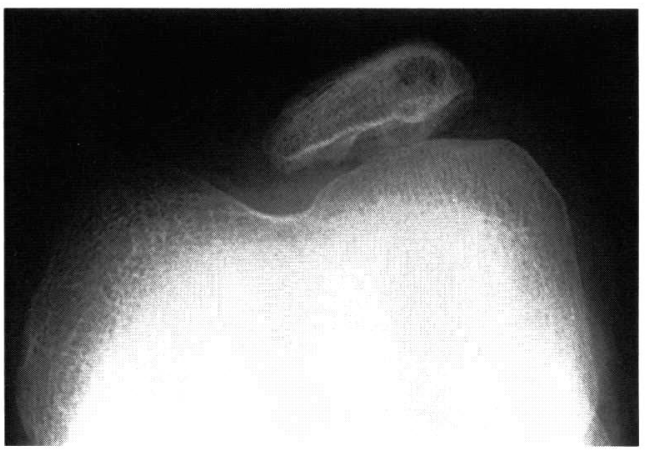

術後 5 年

図 5 症例 212 歳 男性

nail-patella 症候群の恒久性膝蓋骨脱臼（unsatisfactory). 術後 5 年で顆間窩の形成はみら れるが、亜脱臼を呈した。

過は良好であった（図 6).

症例 4:13 歳女性, 習慣性膝蓋骨脱臼で, 結果は unsatisfactory である. 術前, 屈曲 $20^{\circ}$ で脱臼を呈 する. 術後 5 年で $30^{\circ}$ 屈曲位では顆間窩の成長が見 られず，再脱臼しているが， $60^{\circ}$ では整復され，顆間 窩の形成もみられる。この症例では著しい顆間曧低形 成があったこと, 術中外側解離による充分な整復位が 得られなかったことが原因として挙げられた（図 7）.

\section{考察}

膝蓋骨脱臼の素因として, 様々な要因が挙げられる が, 膝伸展機構の作用方向の異常, 骨形態異常, 関節 弛緩が大きな要因に挙げられる。これら病態を把握し たうえで治療法を選択せねばならない. しかし膝蓋骨 脱臼に対する手術法は，100 種以上とも云われており， このことは確実な方法が未だないことを意味している.

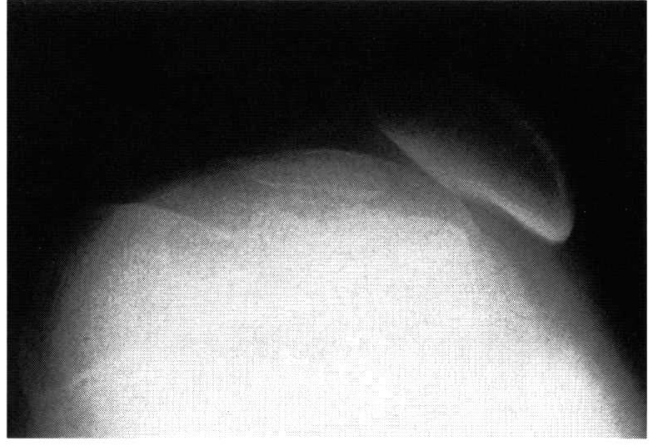

術 前

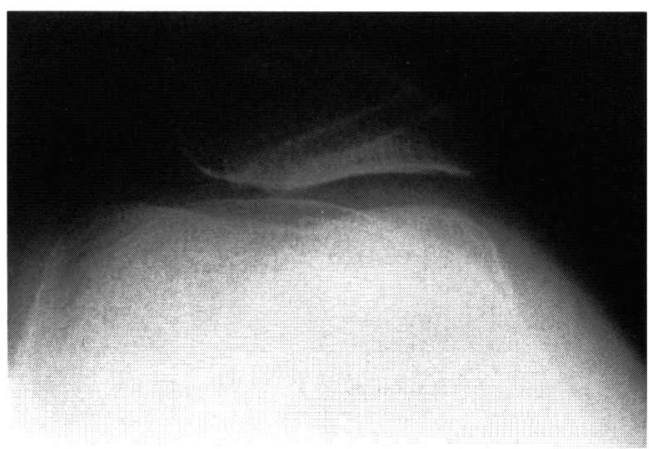

術後 2 年

図 6 症例 312 歳 女性 習慣性滕蓋骨脱臼 (satisfactory). 術後 2 年で 顆間曧はやや浅いが経過は良好であった。

手術法を選択する際，まず骨端線閉鎖の前後により， 骨性手術か，軟部組織のみによる整復かが決定される。 骨端線閉鎖前に Hauser 法や Elmslie-Trillat 法に 代表される脛骨粗面移行を行うと, 二次的に反張滕や 外反変形などを惹起するため, 一般的に施行すべきで はない，軟部組織のみによる整復術式の中で, 我々は 上崎法を応用している。, 上崎法は外側解離と内側縫縮 で膝蓋骨を staticに整復し, 更に膝屈筋力の動的作 用を利用して dynamicに整復位を保持する proximal realigmentであり, dynamic tenodesis と考 えられる。豊永 ${ }^{12}$, 成田 ${ }^{8)} ら は$ 移行した半腱様筋腱が dynamic に制動していることを筋電図学的に証明し ており，この方法は骨端線閉鎖前の小児で強固な制動 を要する例に適応があると思われる.

今回我々は, 整復後の顆間窩の骨性成長に着目し, 術前後の sulcus angle と年齢との推移を検討した。 
術 前
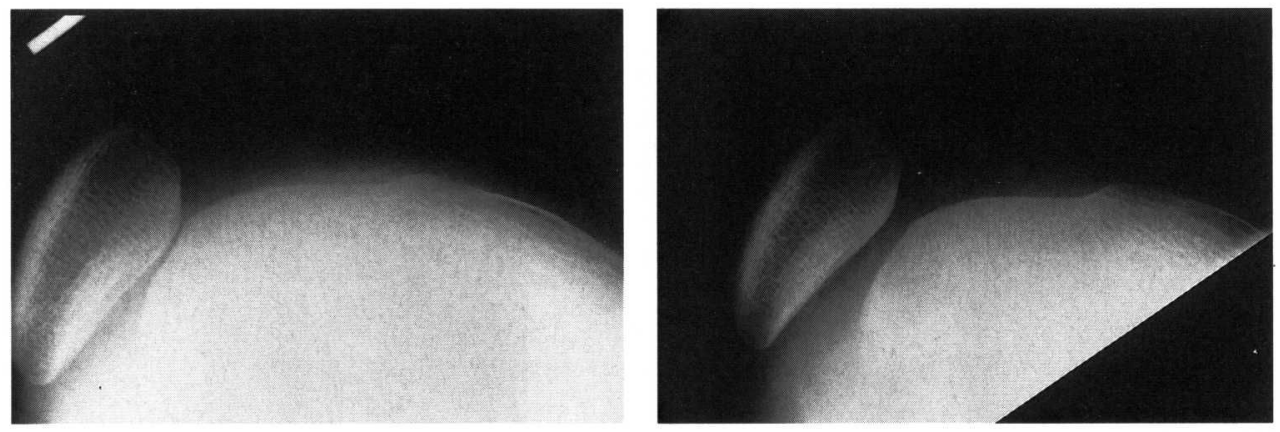

術後 5 年
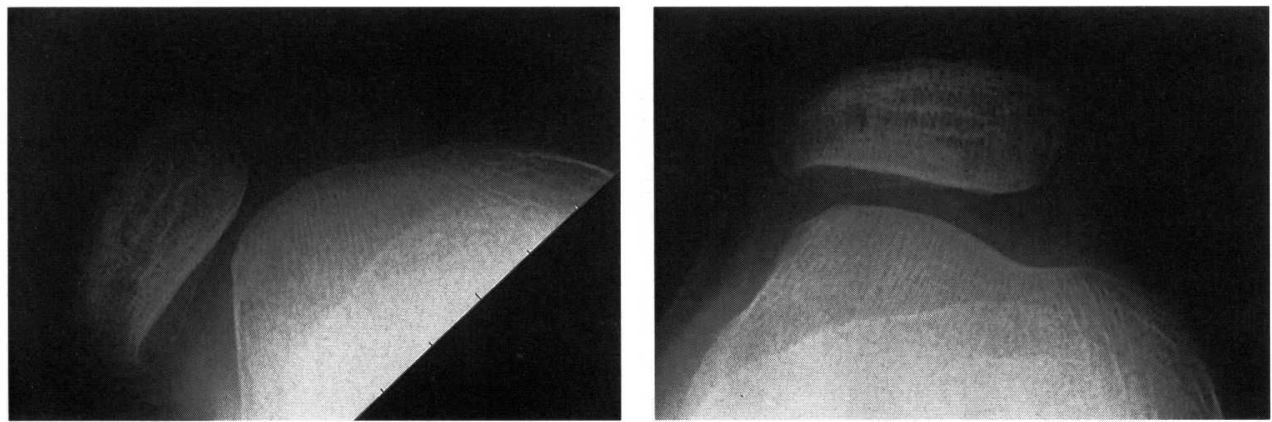

図 7 症例 4 13 歳 女性

習慣性膝蓋骨脱臼 (unsatisfactory). 術後 5 年で $30^{\circ}$ 屈曲位では顆間窩の成長見

られず，再脱臼しているが， $60^{\circ}$ では整復され，顆間窩の形成もみられる。

経過年数は違うが，年齢とともに顆間窝は形成され， 膝蓋骨整復とともに，顆間窩の骨性成長は促進される ことを示唆した。また顆部未成熟の段階では, その成 長は整復後, より促進される傾向があった. 即ち, 正 しい tracking を与えることにより可塑性のある軟骨 が良好な形状に成長するのではないかと考えられた。 このことより, 治療を行う時期としては, 可及的早期 の手術による整復が重要であると考えられた。 また思 春期以降の骨性変形の強い症例, 顆間窩低形成の残る 症例は, 正しい整合性を得るには骨性手術などの併用 が必要であると思われた。

また幼小児に対する早期診断を目的とし MRIによ る評価を施行した（図 8). 症例は 6 歳男性, nailpatella 症候群で, 膝蓋骨低形成のため X 線上, 膝 蓋骨は描出されず, MRIにて形態を把握した。短期 経過症例であるが, MRIは術前後の膝蓋骨, 大腿骨 顆部の形態の把握に有用であると思われた。また，顆 間窩の術後成長は MRIにて経時的に観察する必要が あると思われる。
ま と め

(1)小児の膝蓋骨脱臼に対し，上崎法を施行した 11 例 15 膝を検討した。

(2) 15 膝中 12 膝は臨床的, X 線学的に良好な結果で あった. 3 膝は再脱臼, 亜脱臼位を呈し, これらは年 長児の手術例であった.このことより加齢に伴う二次 的変形が生じる前に早期に整復することが必要と思わ れた。

(3)小児では可及的早期に膝蓋骨を整復保持すること で, 術後の顆間曧の良好な骨性成長が期待できると思 われた。

(4)恒久性脱臼の早期診断には MRI が有効であった.

\section{参 考 文 献}

1) Baksi. P.D.: Pes Anserius Transposition for $\mathrm{Pa}$ teiiar Dislocations, Long-Term Follow-Up Results. J.B. J.S (Bri), 75-B : 305-310, 1993.

2) Bergman. R. et al.: Habitual Dislocation Of The 


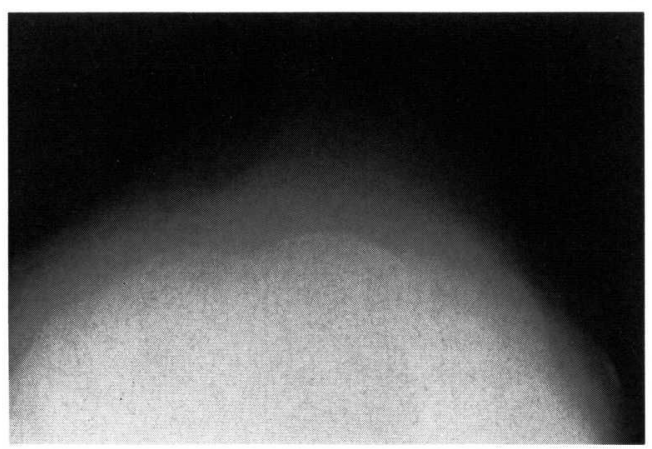

単純 X 線

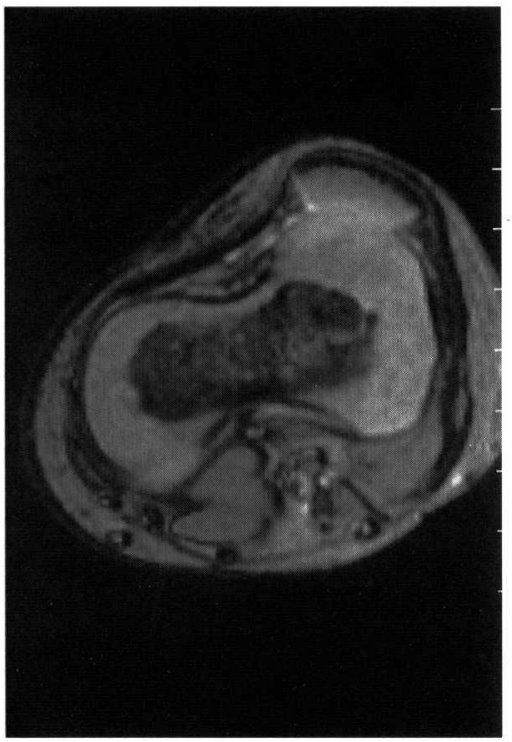

MRI

図 86 歳 男性

nail-patella 症候群で, 膝蓋骨低形成のためX 線上, 膝蓋骨描出されず, MRIに て形態が把握できた。

Patella In Flexion. J. B. J.S (Bri), 70-B : 415-419, 1988.

3）坊 明彦ほか：当科におけるいわゆる習慣性膝蓋骨脱 臼に対する治療経験。関節外科, 15(11) : 100-103, 1996.

4）富士川恭輔ほか：習慣性膝蓋骨脱臼，特に小児習慣性 膝蓋骨脱臼について。関節外科, $5: 253-261,1986$.

5) Gao. G-X. et al.: Surgical Management of Congenital and Habitual Dislocation Of The Patella J. Pediatr. Orthop, $10: 255-260,1990$.

6）小林 晶: 若年者にみられる膝蓋大腿関節障害の診断. 整形外科, $40: 115-124,1989$.

7) Langenskiold. A. et al.: Congenital Dislocation of the Patella and Its Operative Treatment. J.Pediatr. Orthop, $12: 315-323,1992$.

8）成田哲也ほか：膝蓋骨亜脱臼症候群に対する上崎法の 成績. 東京膝関節学会誌, $11: 52-57,1990$.
9）越智光夫ほか：膝蓋骨脱白に対する腱制動術について, Isometricityの観点より. 滕, $15: 40-45,1990$.

10）佐々木雅仁ほか：いわゆる膝蓋骨脱臼に対する手術療 法の検討. 整形外科, 41(8): 1161-1168, 1990.

11) Stanisalvjevic. S. et al.: Congenital, Irreducible, Permanent Lateral Dislocation of the Patella. Clin. Orthop, $116:$ 190-199, 1976.

12）豊永敏宏ほか：膝蓋骨疾患におけるCybex- IIによる 膝伸展 - 屈曲力の検討. 整形外科と災害外科, 32(4)： 1219-1225, 1984

13）上崎典雄ほか：小児習慣性膝蓋骨脱臼に対する新しい 手術法. 膝, $1: 24-27,1975$.

14）上崎典雄ほか：習慣性膝蓋骨脱臼の治療. 臨整外, 12 ： 587-590, 1977.

15）上崎典雄ほか：習慣性膝蓋骨脱臼に対する治療. 膝, $13: 122-124,1987$. 